\title{
RESPONSE OF COCONUT TO INCREASING LEVELS OF LEAF PRUNING AND ITS IMPLICATIONS ON FARM PRODUCTIVITY
}

\author{
By \\ S.S. Magat, L.H. Canja and R.Z. Margate ${ }^{1}$
}

\begin{abstract}
Effects on nut production and copra (wt/nut and yield/tree of four leaf pruning conditions (LP): control (no LP); LP from leaf 24; leaf 19 and leaf 14 with 31, 23, 18 and 13, remaining leaves on each palm, respectively, was studied on adult bearing palms at the Davao Research Center, Philippine Coconut Authority. As a reference point, leaf 1 is considered as the youngest expanded leaf, while leaf 19, the one supporting the 7-8 month old developing nuts or buko.

Except in the first year of LP of which nut and copra yields under all LP conditions were similar to the unpruned palms, the following second and third years of LP indicated that leaf pruning from leaf 19 or maintaining only the 18 younger, upper leaves of the tree crown strongly showed the capability of the coconut to still support the normal development and maturity of nuts. As a result of LP, sunlight transmission to intercrops increased by about $120 \%$ compared to unpruned palms. This was translated to higher intercrop yield of corn (2.16 t increased to $3.71 \mathrm{t} / \mathrm{ha}$ ) which is strongly attributed to the average 4,000 ft candles of sunlight (190.5 PAR) observed with LP from leaf 19 and the rest of the leaves below.

In relation to increased sunlight transmission, intercropping, water economy and drought tolerance, pest and disease control and added income from pruned leaves, implications of LP are pointed out.
\end{abstract}

\section{INTRODUCTION}

The effect of the removal or pruning of leaves of coconut on its production is not well understood. In fact, during harvesting, to facilitate the process of cutting harvestable bunches, leaves are usually removed. In Davao, Southern Mindanao, only few leaves (5-10) are left to allow adequate sunlight for the normal development and high yields of intercrops as ramie and other annual crops.

Depending on the extent of pruning of palms, some workers obtained adverse effects (Bailey et al. 1977; Calvez 1976). However, other workers reported beneficial effects of the practice on plants (Gifford and Evans 1981; Detling et al. 1979; Heichel and Turner 1985). In coconut, it should be very useful to understand the response of palms (in terms of nuts and copra) to pruning as this has several implications on cultural and cropping systems as intercropping, irrigation, drought tolerance, pest control management, as well as additional income from sale of pruned leaves and their by-products.

This paper presents the three-year findings from a pruning trial conducted at the Philippine Coconut Authority (PCA) Davao Research Center, Bago-Oshiro, Davao City, Southern Mindanao, Philippines.

1 Davao Research Center Philippine Coconut Authority Bago-Oshiro, Davao City, Philippines 


\section{METHODOLOGIES}

The study was conducted on 35-yr-old Laguna Tall palms grown on Tugbok clay loam soil (typic Tropudalfs), $11 \mathrm{~km}$ (inland) from the coast, $120 \mathrm{~m}$ altitude. As described earlier (Magat et al, 1981), the soil is deep, well-drained, slightly acidic ( $\mathrm{pH} \mathrm{6.5),} \mathrm{with} \mathrm{high} \mathrm{base} \mathrm{saturation} \mathrm{(70 \% ).} \mathrm{The}$ area is deficient in $\mathrm{N}, \mathrm{S}$, and $\mathrm{C} 1$ thus coconuts are fertilized with $\left(\mathrm{NH}_{4}\right){ }_{2} \mathrm{SO}_{4}$ plus $\mathrm{KC1}$ or $\mathrm{NaCl}$, at least every 2 years.

In this trial, the four leaf pruning treatments (LP) with four experimental palms per treatment are replicated four times and laid out in a Randomized Complete Block Design (RCBD).

Mature nuts were harvested every 45 days ( 8 times per year) in which 20 nuts/plot were sampled for copra weight/nut as basis of copra yield (yield/tree x copra/nut).

The benchmark nut production among experimental plots is very similar (statistically insignificant) and average number of leaves before the LP treatment was 31 leaves. As a point of reference (illustrations $1.1,1.2,1.3,1.4$ ), leaf \#1 is the newly opened or youngest expanded leaf. The number of leaves in each treatment were as follows:

TREATMENT

$\mathrm{T} 1$

$\mathrm{T} 2$

T3

$\mathrm{T} 4$

$$
\text { - } \quad \text { Control (no LP) }
$$

- $\quad$ LP from leaf \#24 a

- $\quad$ LP from leaf \#19 b

LP from leaf \#14 c

\section{NO OF LEAVES}

(Remaining)

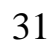

23

18

13

a - leaf supports 12-mo-old harvestable nutbunch

b - leaf supports 7-mo-old buko (softmeat) nutbunch

c - leaf supports 3-mo-old fist-size nutbunch

Every harvest time of mature nuts (45 days), the remaining number of leaves were maintained at 23, 18 and 13 for T2, T3 and T4, respectively. About $0.75 \mathrm{~m}$ of leaf fronds (supporting developing nutbunches) were allowed to remain attached to the trunk.

\section{RESULTS AND DISCUSSION}

\section{Effects of leaf pruning on production}

In the first year of pruning, nut production of palms with leaf pruning (LP from leaf 24 and below, from leaf 19 and from leaf 14) did not differ significantly with those without LP (Figure 1.1). Likewise, palms with LP from leaf 24, leaf 19 and leaf 14 were not significantly different with each other. The same trend was observed during the second and third year of LP, however, reduction in nut yield by 29\% (year 2) and 20\% (year 3) was observed on palms with LP from leaf 14 (supporting fist-size nuts) compared to unpruned (without LP) palms. In the third year, palms with LP from leaf 19 (18 upper leaves maintained) yielded the highest number of nuts (100/tree), 40\% and 53\% higher than palms unpruned and LP from leaf 14, respectively.

Results clearly indicated that for one year pruning, even the remaining 13-18 leaves was capable of providing palms with adequate physiological support as nut yield was not impaired and these number of younger leaves were apparently more functional and physiologically active than the lower, older 18 leaves. But $\mathrm{f}$ or the next two years (year 2 and 3), leaf pruning from leaf 19 
(supporting the tender 8 month old nut or buko) e.g. maintaining only the upper, younger 18 leaves were able to support high nut production (80-100 nut/tree/year). This indicates that maintaining these leaves (18) could still provide the desirable yield levels and at the same time gives additional sunlight for intercrop grown under coconut.

Thirty years ago (Dolar, 1960) mentioned that the 10-12 older leaves of a mature coconut had little value as that leaves had already passed their productive stage and thus, could be removed to divert nutrients and other growth factors to more physiologically active parts of the palm.

\section{Effect of leaf pruning on weight of copra}

The copra weight per nut $(\mathrm{g})$ of palms under all pruning treatments (without LP, LP from leaf 24, LP from leaf 19 and LP from leaf 14) did not vary significantly for the first, second and third years of LP (Figure 1.2). This shows that LP does not affect the copra wt/nut, even with heavy LP (from leaf 14 and from leaf 19) e.g. maintaining only 13-18 younger leaves.

The consistent increase in average copra wt from first year of $161 \mathrm{~g}, 170 \mathrm{~g}$ and $225 \mathrm{~g}$ cogra/nut respectively, maybe mainly attributed to improvement in the palm nutrition, particularly the leaf $\mathrm{Cl}$, regardless of the degree of LP. Several workers had observed increased wt of copra with increased leaf-Cl up to $0.50 \% \mathrm{Cl}$ (Magat et al 1976, 1988, 1990); Margate et al, 1978).

\section{Effect of leaf pruning on copra yield}

The yield of copra (per palm/year) was not signifi-cantly affected by LP in the first and second year of treatments, even with heavy LP (from leaf 14 and leaf 19) as presented in the figure 1.3. However, in terms of copra yield, palms pruned from leaf 14 (supports fist-size nuts) a yield reduction of $24 \%$ compared to unpruned palms was noted in the second year.

In the third year however, a significant reduction (11 kg copra/palm) in yield was observed in LP from leaf 14 (only 13 leaves maintained compared to LP from leaf 19 (only 18 leaves maintained). Nevertheless, copra yield did not differ significantly in palms without LP, LP from leaf 24 and leaf 19 (Figure 1.3).

As in terms of nut production, copra wt/nut, leaf pruning from leaf 19 did not result in copra yield reduction and therefore the maintenance of only 18 younger, upper leaves could be considered sufficient for the palms to develop normally, supporting all the developing bunches to maturity, even those bunches with pruned leaves (from leaf 19 and down).

Findings of this work supports earlier claims of workers that when leaves are removed, likely the photosyn-thetic efficiency of the remaining leaves are improved (Das Cupta, 1972; Pereira, 1978); mobile nutrients (e.g. $\mathrm{N}, \mathrm{S}, \mathrm{K}$ and $\mathrm{Cl}$ ) and water becomes readily available to the remaining leaves. (Detling et al, 1979, Heichel and Turner, 1983).

\section{IMPLICATIONS OF FINDINGS}

\section{On intercropping}

Pruning to maintain leaves 18 upper younger leaves instead of 28-32 leaves in each tree should be able to allow more sunlight, thus a wider choice of marketable short-season annuals and perennials intercrops. Moreover, as the yield of most intercrops is directly related to the active solar radiation, higher yields are reached resulting in a cropping system that is high in efficiency and cost-effective (higher net income) . 
An example of this improved sunlight transmission is shown in the corn intercrop. At the PCA-Davao Research Center, corn planted under coconuts with leaf pruning were significantly taller and stouter, with higher number of mature ears compared to palms without LP (Table 1). With coconut LP, grain yield is increased by $72 \%$ (2.16 to $3.71 \mathrm{t} / \mathrm{ha}$ ).

The improvement in growth and yield of corn as a result of LP is highly due to the increase in light intensity by $120 \%$ (compared to palm without LP) under 19 year old palms spaced $9 \mathrm{~m}$ in triangular system. Average light intensity of 1,840 ft-candles (without LP) and 4,075 ft-candle (with LP from leaf 19 (were observed (Table 2).

Moreover, suitable intercrops under coconut maybe identified by matching the observed light intensity with the light requirement of selected crops (Annex 1).

\section{On crop water economy and drought tolerance}

The pruning of less functional leaves reduces the water requirement of the palms due to the reduction in the transpiration volume, mainly through the living leaves. The practice of LP from leaf \#24 and leaf \#19, could reduce transpiration of water requirement of palms by about $25-50 \%$. In areas with distinct and regular dry period of 3-6 mo e.g. mostly rainfall less than $100 \mathrm{~mm}$, LP during nut harvest before the onset of the dry season should minimize the adverse effects of drought on fruit set and production.

\section{On pest and disease control}

In cases where damages of pests usually occur on lower and older leaves (leaf \# 19 and below), control measures may be ignored as they likely do not affect the physiological activities, especially the photosynthesis of palms. While in the case of fungus diseases of leaves found in said lower leaves, cutting of these to avoid spread to other leaves of the same trees and other trees should be in order, without worry of a significant nut or copra yield reduction. If this is the case, adjustments on the Economic Threshold Level (ETL) in percent damage should be considered.

Finally pruning the older leaves (from leaf 19) of each bearing tree to a total 12-14 leaves (annual) depending on the practice (from leaf \#24 and leaf \#19) offers additional income for farmers. In some coconut regions, coconut leaves are used for making stick brooms, place mats, fruit baskets, waste baskets, mirror frames, plant holders, roofing and walling materials, etc. produced either small-scale or mediumscale rural industries. In fact, in the Bicol region of the Philippines as bundle (5 cm dia.) of dry coconut midrib sells at 2.50 -3,00 Philippine peso, while a bundle of dry coconut frond for firewood (0.75-1 m length, $25 \mathrm{~cm}$ dia. ) sells at 3-5 Philippine peso/bundle (Arellano, M. pers. comm, 1991). Therefore, this shows that farming communities could derive income not only from selling matured husked nuts, copra, shell/charcoal, and husks/coir fiber, but also from pruned coconut leaves which are of less importance to the maturity of developing bunches of nuts.

\section{CONCLUSION}

This 3-year study clearly showed that coconut leaf pruning (LP) from leaf 19 or maintaining the 18 younger, upper leaves of the crown of the coconut tree is capable of supporting normal development (till maturity) of bunches (nuts) . As a result of the LP, sunlight transmission to the intercrop like corn increased by about $120 \%$ compared to the usual condition (unpruned palms).

For an intercrop like corn which requires sunlight 3,000-8,000 $\mathrm{f} \mathrm{t}$ candles ( 143-381 PAR), the average 4,000 ft. candles of sunlight observed with LP from leaf 19 (e.g. leaf supporting the 8 mo. old developing bunch and the rest below) showed to be highly satisfactory as manifested in the high corn yield (3.7 tha). 
Many field and horticultural crops, especially grain crops, root crops, grain legumes and fruit crops should yield productively and provide high profitability when planted as intercrops of coconuts subject to LP techniques as followed.

\section{ACKNOWLEDGMENT}

The authors express their appreciation to Mr. Maximino, Gelborion, Ms. Monette M. Berdulaga and Mr. Joselito Francisco, staff of the Agricultural Research. and Development Branch, Philippine Coconut Authority, for their invaluable assistance in the gathering of research data and drafting the paper. 


\section{REFERENCES}

BAILEY, P. (1977). Effects of -artificial defoliation on coconut yield in Papua New Guinea. Papua New Guinea Agric. J. 28 (2/3/4): 39-45.

CALVEZ, (1976). Influences on oil palm yield of pruning at different levels. Oleagineux 31(2): 57-58.

DAS GUPTA, D.K. (1972). Effects of decapitation defoliation, and removing part of the root and shoot on subsequent growth of sugar beet. J. Exp. Bot. 23(94): 93-102.

DETLING, J.K. (1979). Net photosynthesis, root respiration, and regrowth of Bouteloval gracilis following simulated grazing. Oecologia: 41: 127134.

DOLAR, S.G. (1961). The environmental factors and cultural practices affecting production of coconut. M.S. thesis, Cornell University, Ithaca, N.Y. GIFFORD, R.M. and L.T. EVANS. (1981). Photosynthesis, carbon partitioning and yield. Annu. Rev. Plant Physiol. 32: 485-509.

HAWKINS, A.F. 1982. Light interception, photosynthesis and crop productivity. Outlook in Agric. 2(3): 104-113.

HEICHEL, G.H. and N.C. TURNER. (198S). Carbon dioxide assimilation of primary and regrowth foliages of old maple and red oak. Response to defoliation. Oecologia 57: 14-19.

MAGAT, S.S., V.L. CADIGAL and J.A. HAVANA (1976). Yield improvement of coconut in elevated inland area of Davao (Philippines) by KC1 fertilization. Oleagineux 30(10): 413-416.

MAGAT, S.S., L.M. ALFORJA and L.G. OGUIS. (1988). An estimation of the critical and optimum levels of leaf-Cl in bearing coconuts: A guide for foliar diagnosis. Phil. J. Coconut Studies 8(2): 6-10.

MAGAT, S.S. and R.Z. MARGATE (1990). The chlorine needs of coconut. CORD-APCC 6(1): 30-51.

MARGATE, R.Z. et al (1978). A long-term KC1 fertilization of bearing coconuts in an inlandupland area of Davao. Phil. J. Coconut Studies 3(4): 1-14.

MOONEY, H.A. and S.L. GALMON. (1982). Constraints on leaf structure and function. BioScience 32: 178266.

PEREIRA, A.S.R. (1978). Effect of leaf removal in the yield components of sunflower. Neth. J. Agric. Sci. 26: 133-144. 


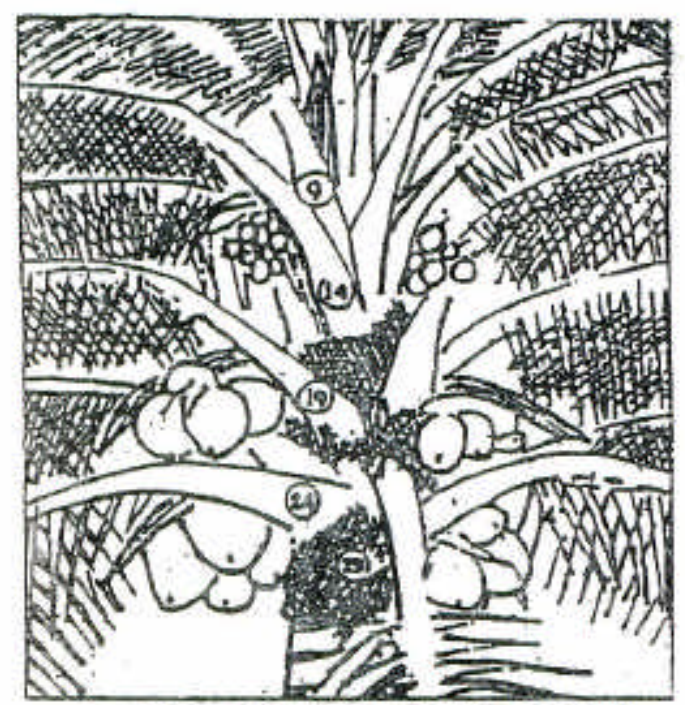

1.1 CONTROL (NO LEAF PRUNING)

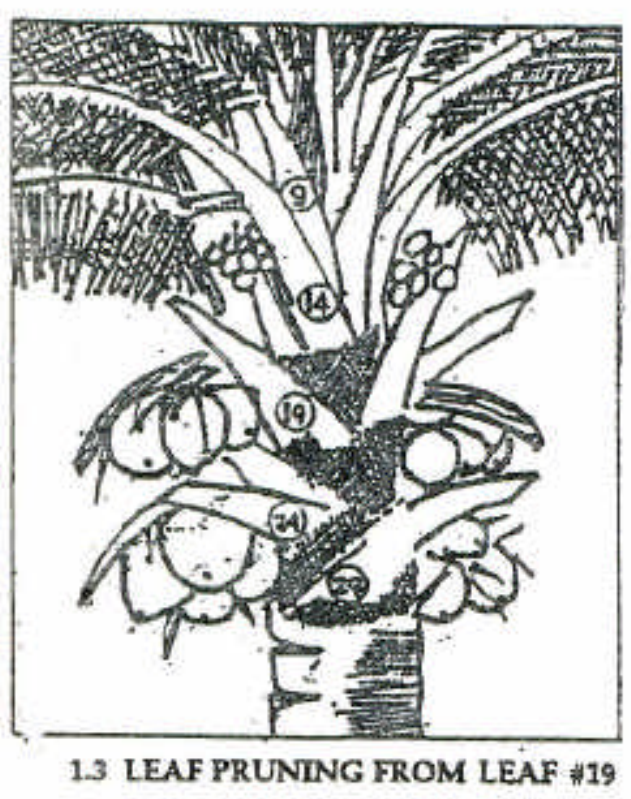

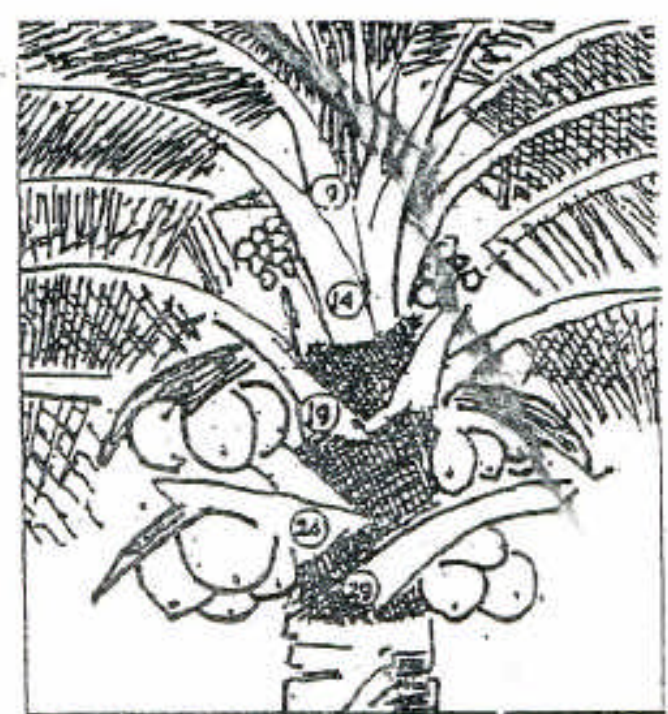

1.2 LEAF PRUNING FROM LEAF $\$ 24$

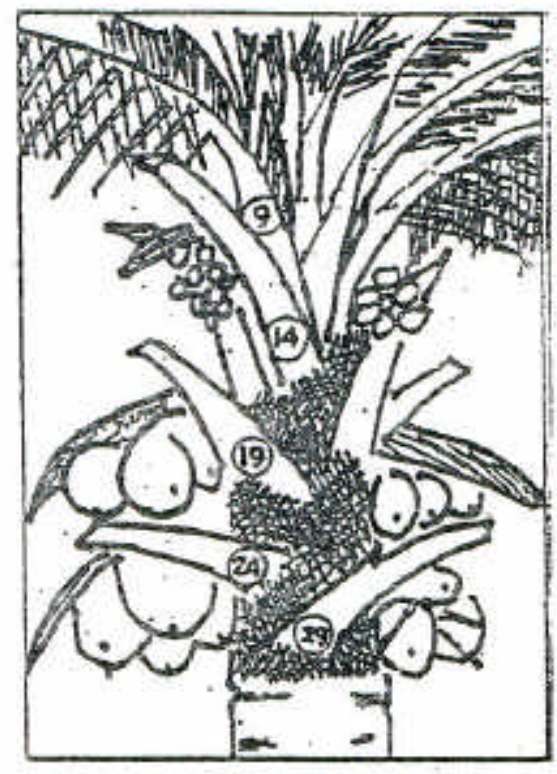

1.4 LEAF PRUNING FROM LEAF औ14

Illustration 1. Coconut Leaf Pruning (LP)under different levels:

1.1 - Control or no LP;

1.2 - LP from leaf 24 (supportting youngest matured bunch with 12 mounth-old nut);

1.3 - LP from leaf 19 (supporting 8-mounth-old) "Buko" nuts;

1.4 - LP from leaf 14 (Supporting fist-size 3 mounth-old developing nuts). 


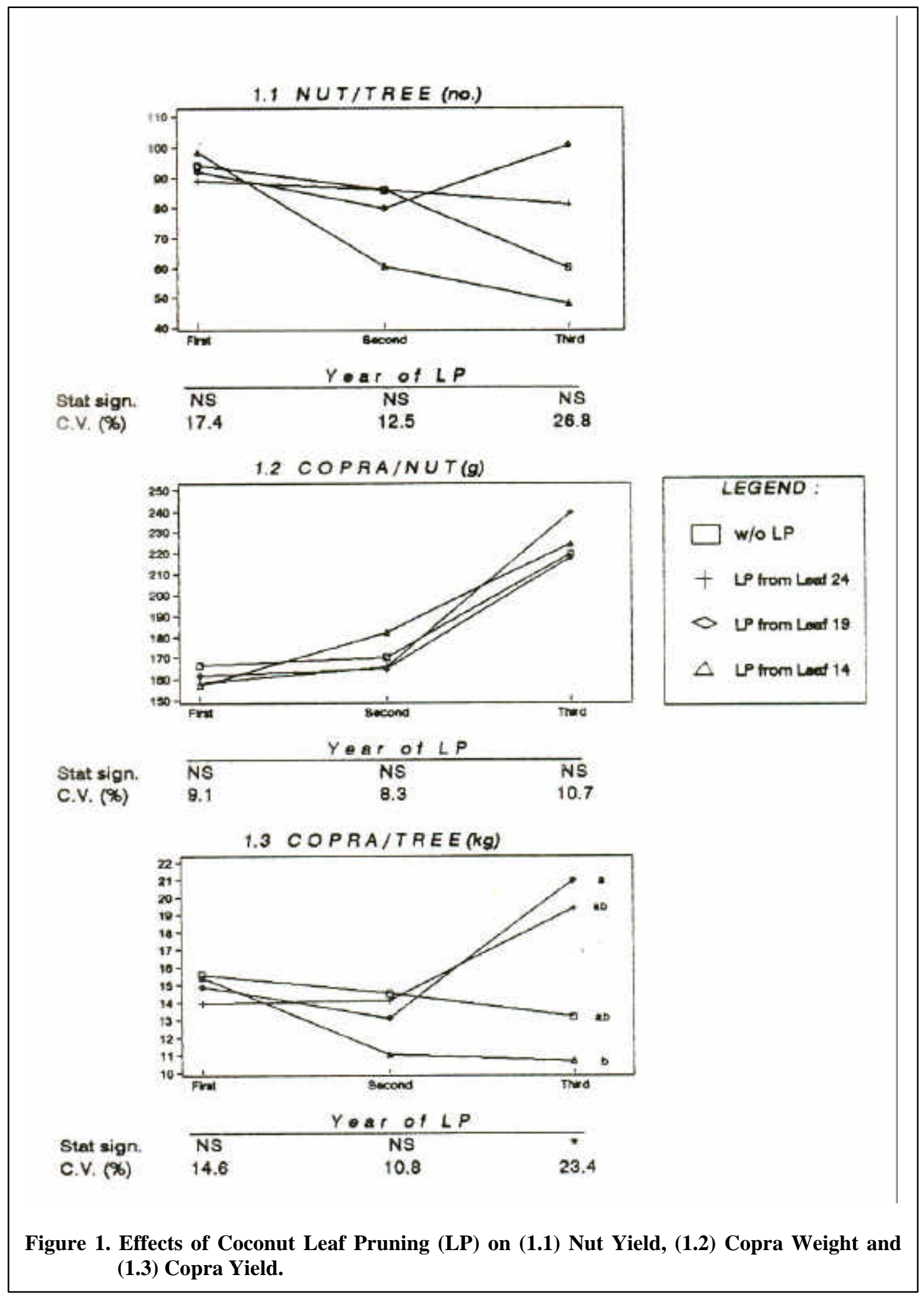


Table 1. Growth indices and grain yield of first corn cropping (wet season) planted under coconut palms with and without leaf pruning (August-December 1993).

\begin{tabular}{|l|r|r|r|r|}
\hline TREATMENT & $\begin{array}{c}\text { MEAN (PLANT } \\
\text { HT) (CM) }\end{array}$ & $\begin{array}{c}\text { MEAN (STEM } \\
\text { DIA) (mm) }\end{array}$ & $\begin{array}{c}\text { EAR } \\
\text { HARVESTED/ } \\
\text { PLOT (no) }\end{array}$ & $\begin{array}{c}\text { GRAIN YIELD } \\
\text { (t/ha) }\end{array}$ \\
\hline Coco w/o LP & 181.13 & 24.35 & 301.26 & 2.16 \\
Coco W/ LP & 215.20 & 26.36 & 415.88 & 3.71 \\
\hline Stat. sig. & $* *$ & $* *$ & $*$ & 1.19 \\
LSD 0.05 & 17.03 & 1.07 & 65.38 & 1.98 \\
0.01 & 28.25 & 1.78 & 108.43 & 22.9 \\
\hline C.V. $(\%)$ & 4.9 & 2.4 & 14.7 & $*$ \\
\hline
\end{tabular}

**highly significant at $1 \%$ level)

*significant (at 5\% level)

N.B. Plot size - 490 sq. m. (corn), 12 palms planted 9 meter triangular system.

Table 2. Comparison of light intensity under open field, coconut + corn intercropping system, w/o coconut Leaf Pruning (LP) and with LP

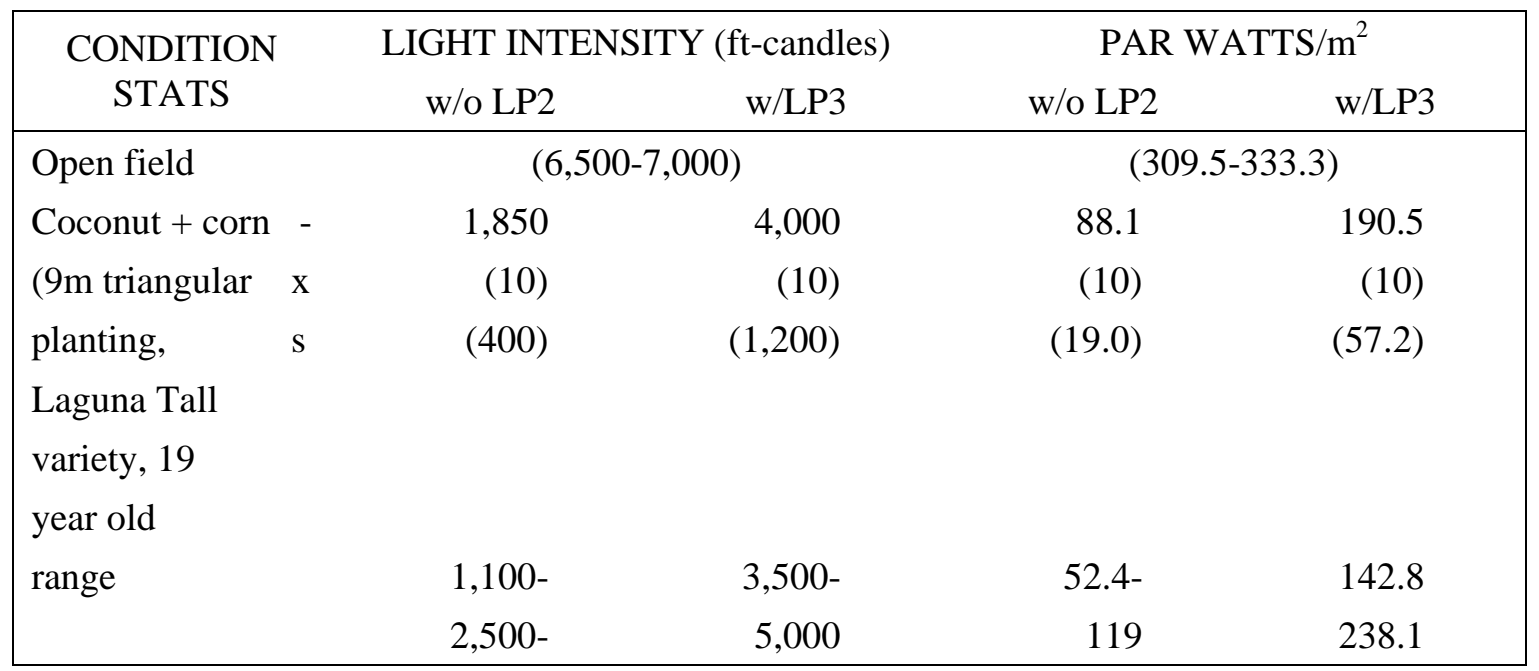

Note : equipment used - GE Type 214 light meter, date and time measured - 9 Jan/94 (10 AM -3 PM, clear sky). Photosynthetically active radiation PAR : conversion factor $\left(1 \text { watt }^{2} \mathrm{PAR}=21 \mathrm{ft} C\right)^{1}$

1 based on Dhopte and Manuel-Livera (1989)

2 normal stand

$3 \mathrm{w} /$ coconut leaf pruning (from leaf 19 e.g. 18

younger/upper leaves remaining) as recommended by Magat and Habana (1992) 
NOTE \# 2 : LIGHT REQUIREMENTS OF SELECTED CROPS (compiled by S.S. Magat, Scientist IV

Reference : Various Sources (Tech. Committee, Environmental Adaptation of Crops, PCARRD and the Soil Management, Support Services, USDA, 1986. Los Banos Laguna, Philippines. PCARRD Bock Series No. 37, 239 p)

Photosynthetically active radiation (PAR) conversion:

$1 \mathrm{watt} / \mathrm{m}^{2} \mathrm{PAR}=21 \mathrm{ft}-\mathrm{c}$ (Dhopte and Manuel-Livera (1989).

\begin{tabular}{|c|c|c|c|}
\hline CROPS & \multicolumn{2}{|c|}{ Range of light Intensity (ft-c) } & \multirow{2}{*}{$\frac{\text { Range of PAR }\left(\mathbf{w a t t} / \mathbf{m}^{\mathbf{2}}\right)}{143-381}$} \\
\hline Banana & $3,000-8,000$ & (Tai, 1977) & \\
\hline Black pepper & $1,000-3,000$ & (Anunciado, 1969) & $48-143$ \\
\hline Cabbage & $2,000-3,000$ & (Edmond et al, 1975) & $95-143$ \\
\hline Cacao & $1,000-3,000$ & (Edmond et al, 1975) & $48-143$ \\
\hline Cashew & $3,000-8,000$ & (Anonymous, 1994) & $143-381$ \\
\hline Citrus & $3,000-8,000$ & (Edmond, et al, 1975) & $143-381$ \\
\hline Coconut & $3,000-7,000$ & (Anonymous, 1994) & $143-333$ \\
\hline Coffee & $1,000-3,000$ & (Edmond et al, 1975) & $48-143$ \\
\hline Corn & $3,000-8,000$ & (Edmond et al, 1975) & $143-381$ \\
\hline Cotton & $3,000-8,000$ & (Edmond et al, 1975) & $143-8,000$ \\
\hline Cowpea & $2,000-3,000$ & (Anonymous, 1994) & 95-143 \\
\hline Cucurbits & $3,000-8,000$ & (Edmond et al, 1975) & $143-381$ \\
\hline Muskmelon & $3,000-8,000$ & (Anonymous, 1994) & $143-381$ \\
\hline Eggplant & $3,000-8,000$ & (Edmond et al, 1975) & $143-381$ \\
\hline Ginger & $2,000-3,000$ & (Anonymous, 1994) & $95-143$ \\
\hline Grapes & $3,000-8,000$ & (Anonymous, 1994) & $143-381$ \\
\hline Lima bean & $3,000-8,000$ & (Anonymous, 1994) & $143-381$ \\
\hline Mangosteen & $3,000-8,000$ & (Anonymous, 1994) & $143-381$ \\
\hline Papaya & $3,000-8,000$ & (Edmond et al, 1975) & $143-381$ \\
\hline Peanut & $2,000-8,000$ & (Edmond et al, 1975) & $95-381$ \\
\hline Pepper (sweet) & $3,000-8,000$ & (Edmond et al, 1975) & $143-381$ \\
\hline Pigeon pean & $3,000-8,000$ & (Anonymous, 1994) & $143-381$ \\
\hline Pineapple & $3,000-8,000$ & (Edmond et al. 1975) & $143-381$ \\
\hline Potato & $2,000-8,000$ & (Edmond et al, 1975) & $143-381$ \\
\hline Rice & $3,000-8,000$ & (Edmond et al, 1975) & $143-381$ \\
\hline \multirow[t]{2}{*}{ Sugar cane } & 6,000 & (Jen-HuChang, 1968) & 286 \\
\hline & (Saturation pt) & & \\
\hline Sweet potato & $3,000-8,000$ & (Edmond et al, (1975) & $143-381$ \\
\hline Tobacco & $3,000-8,000$ & (Edmond et al, 1975) & $143-381$ \\
\hline
\end{tabular}




\begin{tabular}{lrlr}
\hline Tomato & $1,000-3,000$ & (Thompson \& Kelly, & $48-143$ \\
Vanilla & $1,000-3,000$ & (Edmond et al, 1975) & $48-143$ \\
Wheat & 5,300 & (Jen-Hu Chang, 1968) & 252.4 \\
& (Saturation pt) & & \\
Winged bean & $3,000-8,000$ & (Anonymous, 1994) & $143-381$ \\
& & & \\
Ornamental Plants: & & & \\
African violets & $500-1,000$ & (Edmond et al, 1975) & $24-48$ \\
Begonia & $500-1,000$ & (Edmond et al, 1975) & $24-48$ \\
Chrysanthemum & $3,000-8,000$ & (Edmond et al, 1975) & $143-381$ \\
Ferns (most species) & $500-1,000$ & (Edmond et al, 1975) & $24-48$ \\
Gladiolus & $3,000-8,000$ & (Edmond et al, 1975) & $143-381$ \\
Orchids: Dendrobium & $1,000-3,000$ & (Anonymous, 1994) & $48-143$ \\
Stra-leaf vandas & $500-800$ & (Valmayor et al,1977) & $24-38$ \\
Semi-terete vandas & $1,000-3,000$ & (Anonymous, 1994) & $48-143$ \\
Terete vandas & $3,000-8,000$ & (Anonymous, 1994) & $143-381$ \\
Philondendron & $500-1,000$ & (Edmond et al, 1975) & $24-48$ \\
Poinsettia & $3,000-8,000$ & (Edmond et al, 1975) & $143-381$ \\
Rose & $3,000-8,000$ & (Edmond et al, 1975) & $143-381$ \\
\hline
\end{tabular}

Note: $\mathrm{C}^{4}$ plants/crops have the following characteristics:

* optimum temp range for photosynthesis $-30-40^{\circ} \mathrm{C}$

* saturation light intensity $-6,000 \mathrm{ft}$. c

* transpiration rate - low

* net photosynthesis at high temp and light

( $C^{4}$ intensity-high examples: corn, sugar cane, sorghum, coastal bermuda)

\subsection{CONTROL (NO LEAF PRUNING)}

\subsection{LEAF PRUNING FROM LEAF \#24}

\subsection{LEAF PRUNING FROM LEAF \#19}

\subsection{LEAF PRUNING FROM LEAF \#14}

Illustration 1. Coconut leaf Pruning (LP under different levels:

1.1 Control or no LP

1.2 LP from leaf 24 (supporting youngest matured bunch with 12 month-old nuts).

1.3 LP from leaf 19 (supporting 8-mo. old buko nuts.

1.4 LP from leaf 14 (supporting fist-size 3 month-old developing nuts. 